Reduction of the pseudotumor and chronic joint disease is achieved by prophylactic treatment in severe hemophilia.

Calvarial localization of a pseudotumor is unusual [2]. Inflammation due to hematoma causes immune reaction and affects nearby tissues. The skull tables provide natural protection from soft tissues being eroded [3]. All intradiploic lesions should be suspected to be hematomas unless proven otherwise in patients with coagulopathies [2].

Total surgical removal of the hematoma is the treatment of choice. Some authors recommend cosmetic cranioplasty within the same surgical procedure [4]. However, most of them prefer to preserve the intact inner table [5]. According to us, the elastic inner table must be preserved to avoid postoperative complications. Acceptable bone remodeling was seen in the seventh year of follow-up in control CT images. However, a noncompressible inner table must be excised.

In summary, intradiploic hematoma must be expected when an intradiploic lesion is seen with hemophilia. The main part of the surgery is the preservation of the inner table of the cranium in hemophilic patients. Bone remodeling gives good results with time.
Keywords: Hemophilia A, Intradiploic hematoma, Coagulopathy, Intraosseous

Anahtar Sözcükler: Hemofili A, İntradiploik hematom, Koagülopati, İntraosseoz

Conflict of Interest: The authors of this paper have no conflicts of interest, including specific financial interests, relationships, and/ or affiliations relevant to the subject matter or materials included.

\section{References}

1. Rodriguez-Merchan EC. Musculo-skeletal manifestations of haemophilia. Blood Rev 2016;30:401-409.

2. Mobbs RJ, Gollapudi PR, Fuller JW, Dahlstrom JE, Chandran NK. Intradiploic hematoma after skull fracture: case report and literature review. Surg Neurol 2000;54:87-91.

3. Reeves A, Brown M. Intraosseous hematoma in a newborn with factor VIII deficiency. AJNR Am Neuroradiol 2000;21:308-309.

4. Tokmak M, Ozek E, Iplikçioğlu C. Chronic intradiploic hematomas of the skull without coagulopathy: report of two cases. Neurocirugia (Astur) 2015;26:302-306.

5. Dange N, Mahore A, Avinash KM, Joshi V, Kawale J, Goel A. Chronic intradiploic hematoma in patients with coagulopathy. J Clin Neurosci 2010;17:1047-1049.

\title{
The Second and Third Hemoglobin Kansas Cases in the Turkish Population
}

\section{Türk Popülasyonundaki İkinci ve Üçüncü Hemoglobin Kansas Olguları}

\author{
Zeynep Kayra Tanrıverdi1, Arzu Akyay², Aşkın Şen³, Çağatay Taşkapan4, Ünsal Özgen² \\ 1Inönü University Faculty of Medicine, Department of Pediatrics, Malatya, Turkey \\ 2 Inönü University Faculty of Medicine, Department of Pediatric Hematology and Oncology, Malatya, Turkey \\ ${ }^{3}$ FIrat University Faculty of Medicine, Department of Medical Genetics, Elazığ, Turkey \\ 4inönü University Faculty of Medicine, Department of Biochemistry, Malatya, Turkey
}

To the Editor,

We read with great interest the article by Keser et al. [1] regarding the first observation of hemoglobin Kansas in Turkey. The authors described a patient from Malatya as the first case of hemoglobin Kansas in the Turkish population. After the publication of this paper, we had two other hemoglobin Kansas cases from the Malatya region.

Case 1: A 16-year-old female patient was admitted with the complaint of cyanosis of her lips and nails since birth, but she had no problems in her daily life. In her family history, there were other relatives who had the same complaints (Figure 1a). Physical examination of our patient indicated slight cyanosis of her lips, nail beds, and skin (Figure 2). Other system examinations were normal. Transcutaneous oxygen saturation was detected as 50\%. Her complete blood count, electrocardiogram, echocardiogram, methemoglobin level, and peripheral blood smear were normal. In blood gas values, $\mathrm{pH}$ was 7.39, $\mathrm{PCO}_{2}$ was $41.1 \mathrm{mmHg}, \mathrm{PO}_{2}$ was $66.3 \mathrm{mmHg}$, and the P50 value was 66.94 (normal value: 24- 

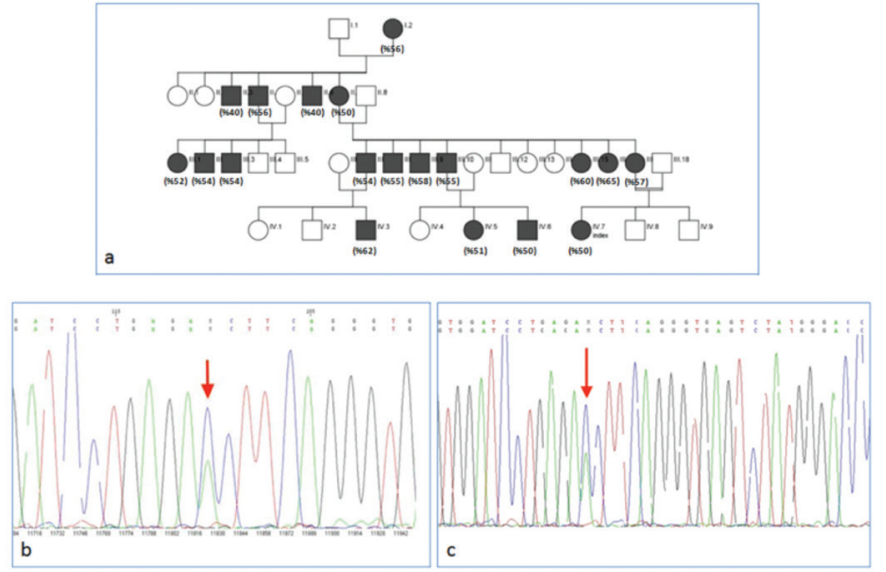

Figure 1. a) Family tree of the patients (transcutaneous oxygen saturations of the affected individuals are shown in parentheses); b) hemoglobin Kansas in DNA sequencing of case $1 ;$ c) hemoglobin Kansas in DNA sequencing of case 2.

29). Hemoglobin electrophoresis revealed $\mathrm{HbA} 1$ of $56.3 \%, \mathrm{HbA} 2$ of $43.5 \%$, and $\mathrm{HbF}$ of $2 \%$. In beta-globulin gene DNA sequence analysis, c.308 A>C ( $\beta 102(G 4)$ Asn>Thr) (Hb Kansas) mutation was detected (Figure 1b).

Case 2: A 43-year-old patient, the mother of Case 1, was admitted with the same complaints as her daughter. Transcutaneous oxygen saturation showed low oxygen levels ( $\left.\mathrm{PO}_{2} 57 \%\right)$. Complete blood count, blood chemistry, and cardiac echocardiography were within normal limits. High-performance liquid chromatography results were as follows: $\mathrm{HbA} 1$ 57.2\%, HbA2 42.5\%, HbF 0.2\%. DNA sequencing revealed the same $A$ to $C$ substitution at nucleotide position 308 as in the first case (Figure 1c).

Hemoglobin Kansas is a rare, unstable, abnormal hemoglobin variant with low oxygen affinity in which asparagine is replaced with threonine in the $102^{\text {nd }}$ position of the $\beta$-globin chain $[2,3]$. In these patients, hemoglobin leaves more than the normal amount of oxygen to extrapulmonary tissues. Therefore, tissues get oxygenated even at low hematocrit levels and patients appear to be healthy. However, cyanosis is seen because the unsaturated hemoglobin amount in the capillaries and veins is higher than $5 \mathrm{~g} /$ $\mathrm{dL}[4]$. The P50 values of these patients are also high $[5,6]$.

In total, six hemoglobin Kansas cases were reported from 1968 to date in the world literature $[2,3,4,5]$. The first hemoglobin Kansas case in Turkey was reported in 2015 [1]. Our patients and 17 other family members who had the same phenotype are more than all of the reported cases in the world literature. We could not perform hemoglobin electrophoresis and genetic evaluations of the other 17 family members because they were living in other

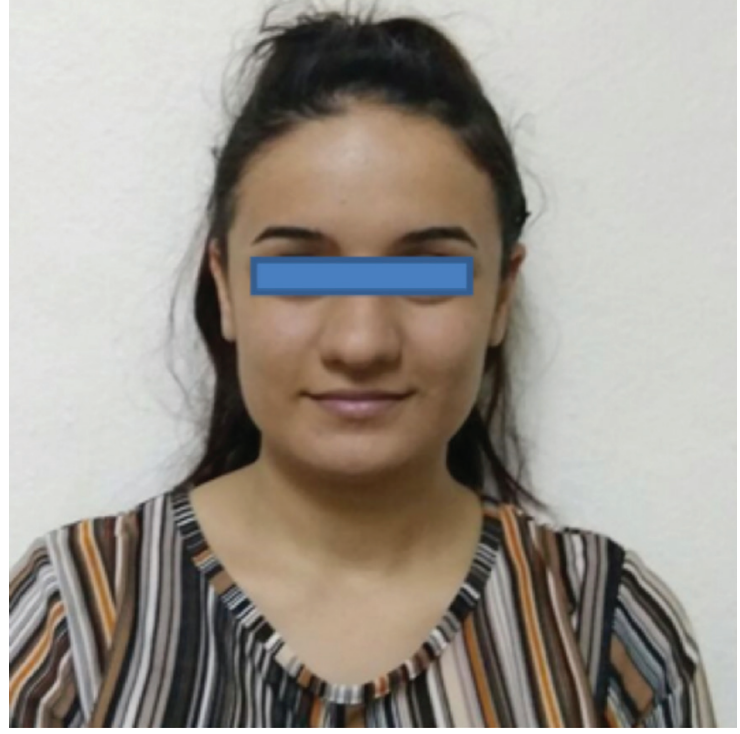

Figure 2. A photograph of case 1 showing cyanosis of her lips. cities. However, these patients had low transcutaneous oxygen saturations, as shown in parentheses in Figure 1a. Hemoglobin Kansas and other unstable hemoglobinopathies with low oxygen affinity should be considered in the differential diagnosis of patients with unexplained peripheral cyanosis.

Keywords: Abnormal hemoglobins, Hb Kansas

Anahtar Sözcükler: Anormal hemoglobinler, Hb Kansas

Conflict of Interest: The authors of this paper have no conflicts of interest, including specific financial interests, relationships, and/ or affiliations relevant to the subject matter or materials included.

\section{References}

1. Keser I, Öztaş A, Bilgen T, Canatan D. First observation of hemoglobin Kansas $[\beta 102(G 4)$ Asn $\rightarrow$ Thr, AAC $>A C C]$ in the Turkish population. Turk J Hematol 2015;32:371-375.

2. Bonaventura J, Riggs A. Hemoglobin Kansas, a human hemoglobin with a neutral amino acid substitution and an abnormal oxygen equilibrium. J Biol Chem 1968;243: 980-991.

3. Morita K, Fukuzawa J, Onodera S, Kawamura Y, Sasaki N, Fujisawa K, Ohba Y, Miyaji T, Hayashi Y, Yamazaki N. Hemoglobin Kansas found in a patient with polycythemia. Ann Hematol 1992;65:229-231.

4. Bonini-Domingos CR, Calderan PH, Siqueira FA, Naoum PC. Hemoglobin Kansas found by electrophoretic diagnosis in Brazil. Rev Bras Hematol Hemoter 2002;24:37-39.

5. Zimmermann-Baer U, Capalo R, Dutly $F$, Saller $E_{1}$ Troxler $H_{1}$ Kohler $M$, Frischknecht $\mathrm{H}$. Neonatal cyanosis due to a new $\mathrm{G} \gamma$-globin variant causing low oxygen affinity: Hb F-Sarajevo [Gy102 (G4) Asn $\rightarrow$ Thr, AAC> ACC]. Hemoglobin 2012;36:109-113.

6. Riggs A, Gibson $\mathrm{QH}$. Oxygen equilibrium and kinetics of isolated subunits from hemoglobin Kansas. Proc Natl Acad Sci U S A 1973;70:1718-1720. 